\title{
A Difficult Metamorphosis: The Incorporation of the Ross Institute \& Hospital for Tropical Diseases into the London School of Hygiene and Tropical Medicine
}

\author{
G C COOK*
}

On 29 June 1934, a large reception, attended by over 600 individuals, was held at the London School of Hygiene and Tropical Medicine (LSHTM) to mark the incorporation of the Ross Institute (RI) into the School; ${ }^{1}$ it remains an integral part of that establishment today. However, negotiations leading to this event had taken almost a year to complete and had been fraught with difficulties, most involving the future role of Aldo Castellani, ${ }^{2}$ who had until then held the appointments of Director-in-Chief, and Director of Tropical Medicine and Dermatology at the Ross Institute \& Hospital for Tropical Diseases (RIHTD). ${ }^{3}$ When Ross died, on 16 September 1932, the Putney establishment was no longer viable (if it ever had been) as an individual entity, and its future was shrouded in uncertainty. ${ }^{4}$ The RIHTD, and subsequently the RI, have until now received relatively sparse coverage in accounts of the history of tropical medicine in England. ${ }^{5}$ Table 1 summarizes the principal dramatis personae in this saga; the Italian physician, Castellani, was always a key player.

${ }^{*}$ G C Cook, MD, DSc, FRCP, FRACP, FLS, The Wellcome Trust Centre for the History of Medicine at UCL, 24 Eversholt Street, London NW1 1 AD.

\footnotetext{
1 'London School of Hygiene and Tropical Medicine: Memorials to Manson and Ross', Lancet, 1934, ii: 56.

${ }^{2}$ Aldo Castellani (1877-1971) was born in Florence; he was educated there and at Bonn and had joined Dr (later Sir) Patrick Manson at the London School of Tropical Medicine in 1901. He made several significant contributions to tropical
}

medicine and later set up in private practice in London. See his autobiography: A Castellani, Microbes, men and monarchs: a doctor's life in many lands, London, Gollancz, 1960; and G C Cook, 'Aldo Castellani FRCP (1877-1971) and the founding of the Ross Institute \& Hospital for Tropical Diseases at Putney', J. med. Biog., 2000, 8: 198-205.

${ }^{3}$ G C Cook, From the Greenwich hulks to old St Pancras: a history of tropical disease in London, London, Athlone Press, 1992, pp. 242-66.

${ }^{4}$ Ibid., p. 261.

${ }^{5}$ Ibid., pp. 259-66. 


\section{GC Cook}

Table 1

Principle dramatis personae; many were closely involved in the negotiations

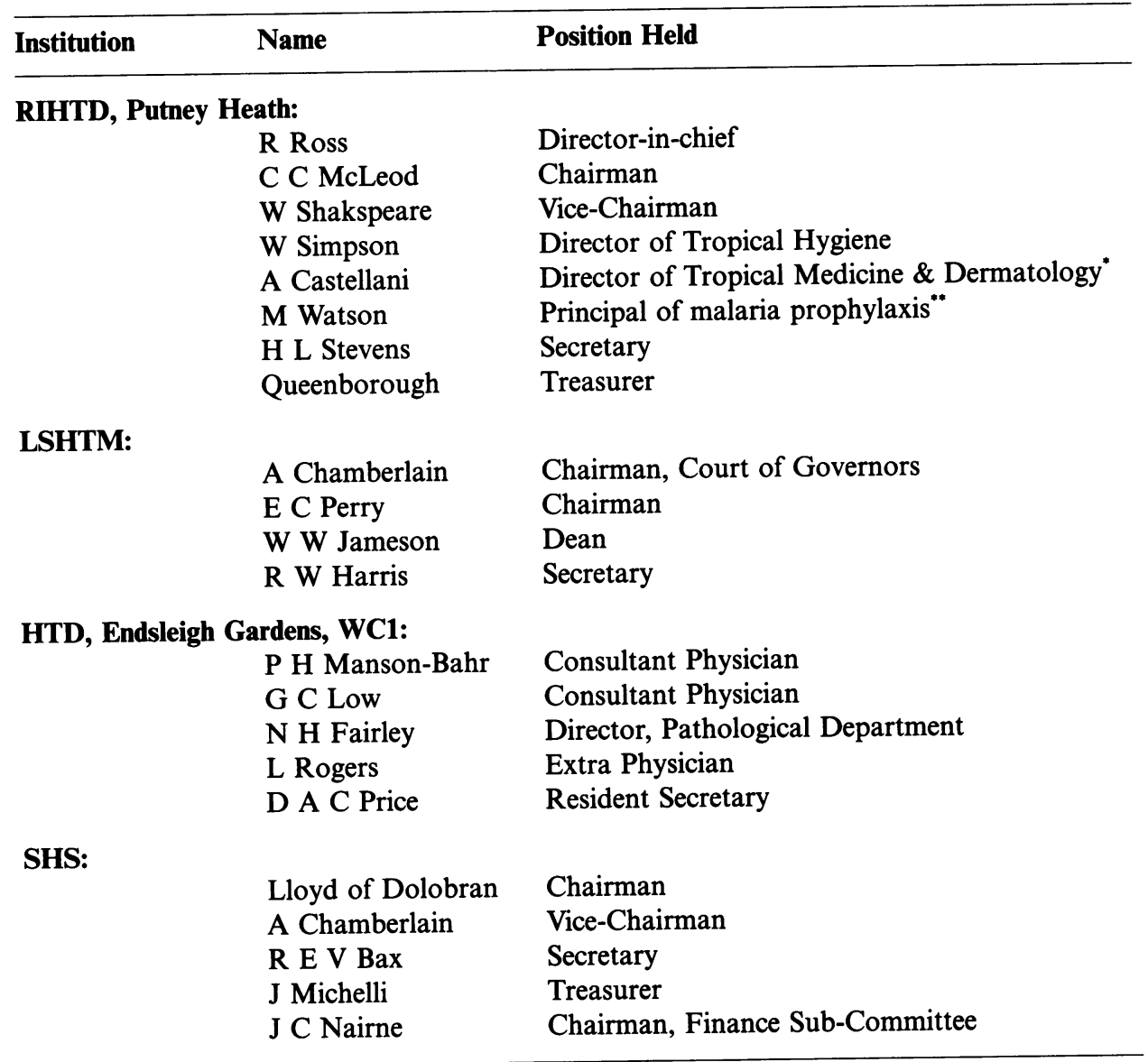

*Castellani became Director-in-Chief following Ross's death on 16 September 1932.

**After Simpson's death on 20 September 1931, Watson became Director of Tropical Hygiene and

Principal of the Malaria Department.

\section{Foundation of the RIHTD}

The RIHTD was officially opened at Putney by the Prince of Wales on 15 July $1926 .^{6}$ The project had been launched three years previously with an appeal for public subscriptions, through a letter to The Times of 22 June 1923 with thirty-three signatories of which H H Asquith (a former Prime Minister) was the

\footnotetext{
${ }^{6}$ The opening of the Ross Institute \& Hospital for Tropical Diseases Putney Heath, London, S.W.15 by H.R.H. the Prince of Wales, K.G. On
}

July 15, 1926, London, John Bale, Sons \& Danielsson, 1926. 


\section{A Difficult Metamorphosis}

first. ${ }^{7}$ The raison d'être had been to establish a permanent memorial to Sir Ronald Ross FRS (1857-1932), who discovered mosquito involvement in the transmission of Plasmodium spp infection in 1897, unravelled the complete life-cycle of avian malaria in 1898, and won the Nobel Prize for Medicine and Physiology in 1902. ${ }^{8}$ Unfortunately, the RIHTD was never well financed or endowed. It was clear to most observers that London, in any case, did not require a second hospital for tropical diseases; ${ }^{9}$ the number of tropical cases at the original London School of Tropical Medicine (founded by Patrick Manson and Joseph Chamberlain in 1899) at the Albert Dock Hospital site had always been insufficient for teaching and research purposes. ${ }^{10}$ When the hospital was moved to 25 Gordon Street, Endsleigh Gardens, London, WC1, in 1920, numbers of inpatients had increased markedly, but still remained relatively low for teaching and research.

Following the initial appeal, a "few thousand pounds" were collected and a "suitable freehold property to contain the Institute and Hospital" was sought. The initial objective of the Institute was "to assist the Empire with its malaria problem". Ross himself felt that "research in malaria and the practical application of his discovery would be accelerated and extended". ${ }^{11}$ In March 1925, "Bath House [West Hill], Putney Heath was secured freehold";12 by the end of that year "the Institute was finally completed and equipped". The Interim Report (like all subsequent reports written by the Chairman, Sir Charles McLeod ${ }^{13}$ (Figure 1) highlighted: "The urgent need of an Institute devoted to research work in the treatment and prevention of tropical diseases [the necessity of which] becomes more and more fully realized". The precise aims were: "(1) To carry on intensive research work in the prevention and treatment of tropical diseases and to assist

\footnotetext{
${ }^{7} \mathrm{H}$ H Asquith et al., 'Tropical Diseases: the debt to Sir Ronald Ross: proposed institute as monument', The Times, 22 June 1923, p. 15; leading article, 'A Ross Institute', ibid., p. 15.

${ }^{8} \mathrm{R}$ Ross, Memoirs: with a full account of the great malaria problem and its solution, London, John Murray, 1923; G C Cook, 'Ronald Ross (1857-1932): 100 years since the demonstration of mosquito transmission of Plasmodium spp.- - on 20 August 1897', Trans. R. Soc. Trop. Med. Hyg., 1997, 91: 487-8; E R Nye, M E Gibson, Ronald Ross: malariologist and polymath: a biography, London, Macmillan, 1997.

${ }^{9}$ Cook, op. cit., note 3 above, p. 266.

${ }^{10} \mathrm{G}$ C Cook, “"Tropical” cases admitted to the Albert Dock Hospital in the early years of the London School of Tropical Medicine', Trans. R. Soc. Trop. Med. Hyg., 1999, 93: 675-7.

${ }^{11}$ RIHTD, Annual Report for 1932, published 1933, p. 21.

${ }_{12}^{12}$ This property was built between 1876 and 1885 , and in its early days was called "Oliva"; its name was changed to "Bath House" some time
}

between 1894 and 1919. Following the move of the RIHTD from this site in 1934, the building and grounds were soon placed on the market ( $\mathrm{J}$ D Wood \& Co, 23 Berkeley Square W1 was the sole agent-Daily Telegraph, 9 Jan. 1934). The house was demolished shortly afterwards, and Ross Court (a large block of flats) opened on the site in 1936; the former "stables" survive, renamed "the Cottage"; London School of Hygiene and Tropical Medicine (University of London) incorporating the Ross Institute, Ross Jubilee 1898-1948: reception on the occasion of the fiftieth anniversary of the discovery by Sir Ronald Ross of the route of transmission of malaria. Monday, $5^{\text {th }}$ July, 1948 5-8 p.m., London, Berryman, 1948.

${ }^{13}$ Sir Charles Campbell McLeod, Bt (1858-1936) was a businessman who had founded a firm in Calcutta in 1887; he subsequently became Chairman of the Royal Empire Society, the National Bank of India, and the London and Lancashire Insurance Company. He was also closely associated with various tea companies. 


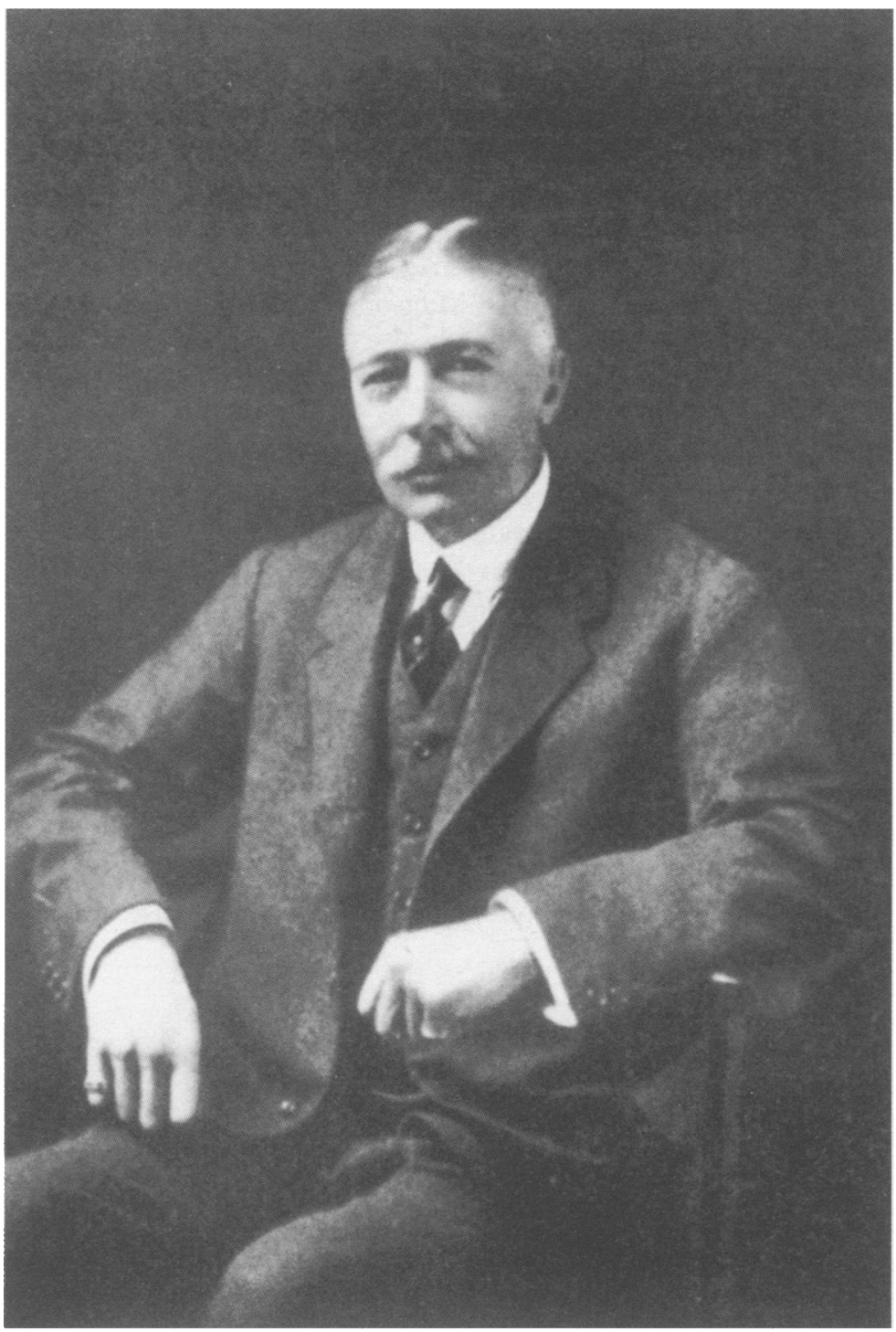

Figure 1: Sir Charles McLeod, Chairman of the RIHTD. (From the programme for a Reception on the occasion of the fiftieth anniversary of the discovery by Sir Ronald Ross of the route of transmission of malaria, London, Berryman, 1948, p. 34.)

medical men interested in tropical diseases to carry out research work. (2) To receive in the Hospital and treat sufferers from tropical diseases. (3) To create more interest in malaria and disease control work and assist such work in every possible manner". The major thrust of research (the three laboratories, but not 


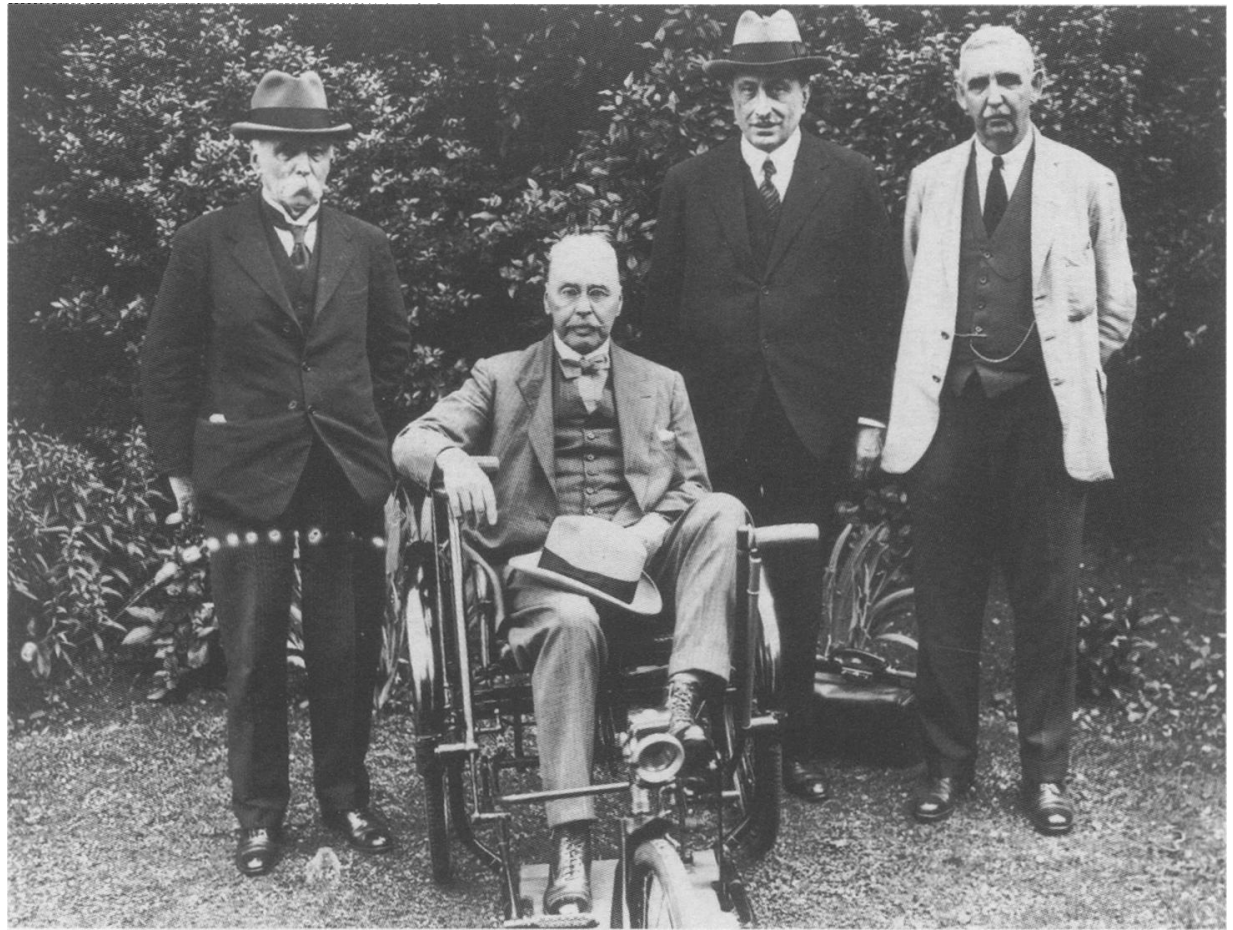

Figure 2: Photograph taken in 1930 showing from left to right: William Simpson, Ronald Ross (in the wheelchair), Aldo Castellani, and Malcolm Watson (London School of Hygiene and Tropical Medicine archive, reproduced with permission).

the hospital, which had been open since October 1925) was directed towards tropical diseases (especially malaria), cancer and smallpox. The hospital component (never a top priority of Ross) "should prove a boon to those returning from the tropics in broken health". ${ }^{14}$ Sir Malcolm Watson (a member of Council) ${ }^{15}$ had sent an address to "all subscribers of the Institute", and Ross himself had visited Ceylon at the invitation of the London-based Ceylon Association, and planned to visit India, at the invitation of the Indian Tea Association and also Malaya "at the end of the year", to advise on malaria control. Subscribers, the Interim Report continued, "may ... help considerably by bringing to the notice

${ }^{14}$ RIHTD, Interim Report, published 20 May 1926, pp. 3-5.

${ }^{15}$ Sir Malcolm Watson, MD, LLD (1873-1955) was Principal of the Malaria Prophylaxis and Control Department and Director of Tropical Hygiene at the RIHTD from 1928 to 1933 . He subsequently became Director of the RI at the LSHTM from 1933 to 1942.

Most of his career was spent in malaria eradication programmes overseas, especially in India, Malaya, and Northern Rhodesia (now Zambia). 


\section{G C Cook}

of public benefactors at home the value and importance to the Empire of research work in the prevention and treatment of tropical diseases". ${ }^{16}$

At the official opening of the RIHTD, which had been the brainchild of Castellani and Sir William Simpson (Figure 2) the Director of Tropical Hygiene, ${ }^{17}$ the Prince of Wales (who was apparently especially interested in the research being carried out on yaws) was welcomed by the President, the Duchess of Portland, and the Chairman, Sir Charles McLeod. The Prince (who "graciously consented to become Patron") spoke of "the work [in the field of tropical medicine] which the British Empire [had] done for civilization", and predicted that "now, thanks to the achievement of one man, whose name we are perpetuating in this Ross Institute [the] ultimate defeat [of malaria] is certain". He was "highly entertained by the care with which Miss Joan Marshall had reared and fed with raisins these troublesome creatures [anopheline mosquitos], which had, nevertheless, recently been discovered to be valuable agents in treating patients suffering from general paralysis of the insane, by infecting them with malaria". In his speech, McLeod emphasized that "research, generally coupled with teaching, is now being conducted in many excellent institutions already established here and in other States"; however, there would be no clash of interests, he continued, as "we do not propose to teach". ${ }^{18}$

Financial support was, however, essential to the project, and the necessity for increased funding was highlighted by Sir Edward Marshall-Hall. ${ }^{19}$ The Organising Secretary, Major $\mathrm{H}$ Lockwood Stevens, estimated that the Institute required "between $£ 8,000$ and $£ 10,000$ per annum to maintain its Research Laboratories and Research Hospital". ${ }^{20}$

\section{Progress of the RIHTD (1926-1932)}

The affairs of the Institute are summarized in Annual Reports for the years 1926 to $1932 .^{21}$ The dominant theme throughout was finance; the Report for 1926 (the first full report), for example, commented: "The year under review has been a very difficult one for a charity such as this, which is at present wholly

\footnotetext{
${ }^{16}$ RIHTD, Interim Report, op. cit., note 14 above, pp. 4, 5 .

${ }^{17}$ Sir William Simpson, CMG, MD, FRCP (1855-1931) was Director of Tropical Hygiene and Physician at the RIHTD until his death. He had previously been Lecturer in Hygiene at Aberdeen University, and in Tropical Medicine at King's College Hospital; he was a former President of the Royal Society of Tropical Medicine and Hygiene (1919-21). Simpson had served on the Advisory Medical Committee on Medical and Sanitary matters to the Secretary of State for the Colonies. He had at various times advised on yellow fever, plague, cholera, dysentery, enteric fever and malaria prevention.
}

\author{
He died at the RIHTD on 20 Sept. 1931; see R A \\ Baker, R A Bayliss, 'William John Ritchie \\ Simpson (1855-1931): public health and tropical \\ medicine', Med. Hist., 1987, 31: 450-65. \\ ${ }^{18}$ The opening of the Ross Institute, op. cit., \\ note 6 above, pp. 4-9. \\ ${ }^{19}$ E Marshall-Hall, 'The Ross Institute', The \\ Times, 24 Aug. 1926, p. 15. \\ ${ }^{20}$ The opening of the Ross Institute, op. cit., \\ note 6 above, p. 13 . \\ ${ }^{21}$ These include the Interim Report, op. cit., \\ note 14 above. The Reports, which included the \\ accounts, were always published in the year \\ following the year they covered.
}




\section{A Difficult Metamorphosis}

unendowed and entirely dependent on voluntary contributions to meet maintenance expenses". ${ }^{22}$ The general strike and the coal strike had both had a serious impact on income. The "purchase of the Institute freehold, structural alterations, fitting up of laboratories, wards and the library, etc., and furnishing" had cost $£ 21,376$ $4 \mathrm{~s} 4 \mathrm{~d}$. The cash assets of the Institute at that time amounted to $£ 8,1263 \mathrm{~s} 2 \mathrm{~d}^{23}$ Financial instability was to continue, however, and the 1929 Report concluded: "The balance in hand ... of $£ 12,000$ does not ... represent prosperity, but simply a reserve to guard against the uncertainty which is always present when an institution is dependent entirely on voluntary contributions". ${ }^{24}$ The financial news in the following Report must have been exceedingly unwelcome: "income for the year from subscriptions, donations and entertainments [had shown] a decrease of $£ 1,500$ " ${ }^{25}$ This was blamed on the "prevailing depression". Further gloomy news emerged in the 1931 Report; there had been a "serious decrease in annual subscriptions and donations [which] from all sources ... amounted to $£ 5,482$ $14 \mathrm{~s}-7 \mathrm{~d}$ " representing a reduction of $£ 2,4191 \mathrm{~s} 10 \mathrm{~d}$ on the previous year; this was "causing the Executive Committee much concern" ${ }^{26}$ However, the following year (during which Ross died) the financial situation had marginally improved: "Donations and subscriptions, etc., from all sources had ... amounted to $£ 6,534-0 \mathrm{~s}-6 \mathrm{~d}$ "-an increase of $£ 1,051$ 5s $11 \mathrm{~d}$. This Report concluded: "While not entirely satisfactory, these figures show a definite improvement on the previous year". ${ }^{27}$

\section{Research Activities}

Early laboratory research was dominated by biochemical reactions of intestinal bacteria, and the symbiotic relationship of certain organisms to various diseases, the "mycological method" of identifying various carbon compounds, and the value of certain fruits in the treatment of some tropical diseases. ${ }^{28}$ Although Castellani published extensively on mycology, he made few significant advances. ${ }^{29}$ Dr J A Shaw-Mackenzie, ${ }^{30}$ aged sixty-nine when the Institute opened, supervised the cancer research; he had apparently developed a blood test to aid in the diagnosis of malignancies, ${ }^{31}$ and had correlated these results with various biochemical indices. ${ }^{32}$ However, his progress also seems to have been exceedingly slow. Work on the "parasite that causes smallpox" seems equally unimpressive. ${ }^{33}$

${ }^{22}$ RIHTD, Annual Report, 1926, p. 6.

${ }^{23}$ Ibid., pp. 12-13.

${ }^{24}$ RIHTD, Annual Report, 1929, p. 20.

${ }^{25}$ RIHTD, Annual Report, 1930, pp. 31-2.

${ }^{26}$ RIHTD, Annual Report, 1931, p. 25.

${ }^{27}$ RIHTD, Annual Report, 1932, p. 48.

${ }^{28}$ RIHTD, Annual Report, 1926, p. 6.

${ }^{29}$ RIHTD, Annual Report, 1929, pp. 17-18.

${ }^{30} \mathrm{John}$ Alexander Shaw-Mackenzie

(1857-1933) graduated (LSA and MRCS) from

University College Hospital, London in 1881. He obtained the MB and MD degrees of the University of London in 1889 and 1895 , respectively. His published work centred on malignant disease, and syphilis in women.

${ }^{31}$ RIHTD, Annual Report, 1928, pp. 24-5. $58-60$.

${ }^{32}$ RIHTD, Annual Report, 1929, pp. 17,

${ }^{33}$ RIHTD, Annual Report, 1927, p. 21. 


\section{G C Cook}

A further line of research involved rheumatic fever and its "possible association" with the rat flea Ceratophyllus fasciatus. ${ }^{34}$

Work on anti-mosquito strategies continued throughout the life of the RIHTD and undoubtedly constituted its major humanitarian contribution. The 1926 Report documented work on malaria prevention in Gibraltar, the Malay States (where the pioneering activities of Sir Malcolm Watson had begun as early as 1901), Burma, and India, ${ }^{35}$ where the acting Viceroy, the Earl of Lytton, had recently unveiled a "portrait tablet" commemorating Ross's 1898 discovery at the entrance to Calcutta General Hospital. The following Report announced that Watson (who had recently retired after many years of malaria control work in the Malay States) had joined the Institute as Principal of Malaria Prophylaxis and Control. ${ }^{36}$ Malaria prevention dominated all other Annual Reports.

Although the list of research publications printed in the 1932 (final) Annual Report seems impressive (159 in all, including addresses and reports), it was cumulative, and included all nineteen publications listed in the Interim Report of $1926 .{ }^{37}$ The majority of the publications (ninety-four) had been published in the Journal of Tropical Medicine and Hygiene, with only a small minority in the Lancet, British Medical Journal, or Transactions of the Royal Society of Tropical Medicine and Hygiene. Ross wrote twelve articles, and sixty-four came from the pen of Castellani who was joint editor (with Simpson) of the Journal of Tropical Medicine and Hygiene between 1926 and 1930 (volumes 29-33), and sole editor from 1931 onwards; during this time, and until his death, Ross was designated Honorary Adviser of this journal.

In summary, there seems no doubt that both clinical researchers and their projects failed to meet national and international standards of excellence; the outcome of the bench research could at best be described as mediocre.

\section{Clinical Component of the RIHTD}

The hospital opened in July 1926 with "half of the beds ... reserved for paying patients at a fee of five guineas inclusive per week". The intention was to "keep about twenty hospital beds in the Institution". ${ }^{38}$ It was never a great success (see Figure 3), but encompassed a variety of diagnoses including: "Chronic Dysentery, Dysentery, Chronic Dysentery and Hepatitis, Chronic Malaria, Malaria, Elephantiasis, Hepatitis, Progenic Granulloma [sic], and Sprue". The following year, cases of "Elephantiasis Nostris", ancylostomiasis, and "Malaria and Tuberculosis"

${ }^{34}$ RIHTD, Annual Report, 1928, p. 26.

${ }^{35}$ RIHTD, Annual Report, 1926, pp. 7-10.

${ }^{36}$ RIHTD, Annual Report, 1927, pp. 13-14.

${ }^{37}$ RIHTD, Annual Report, 1932, pp. 87-96.
${ }^{38}$ RIHTD, Annual Report, 1926, p. 7; R Ross to W Mackinnon, 22 Oct. 1924, Ross Archive, London School of Hygiene and Tropical Medicine. 
A Difficult Metamorphosis

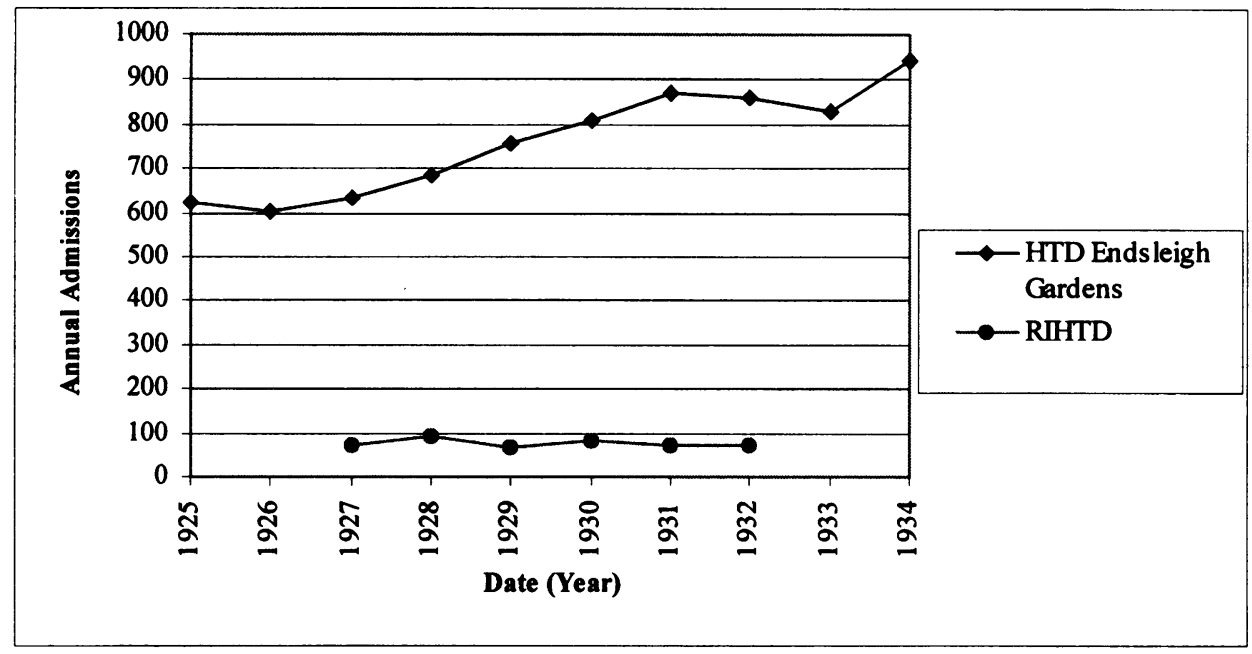

Figure 3: Comparison of annual inpatient admissions to the Hospital for Tropical Diseases, Endsleigh Gardens, with those to the RIHTD. (Created from data taken from the Seamen's Hospital Society's Annual Reports, 1925-34, and the RIHTD's Annual Reports, 1927-32.)

were admitted. ${ }^{39}$ In 1928 the number of inpatients had increased slightly, ${ }^{40}$ and there were twenty-nine outpatients. "Post-dysenteric Colitis" and "Mycosis" were added to the list of diagnoses. But by the following year the number of inpatients was again reduced; to the previous diagnoses were added: "Malarial Polyneuritis", myositis, arthritis, gastric ulcer, duodenal ulcer, Graves' disease, malignant endocarditis, and "amoebiosis". ${ }^{11}$ The next year blackwater fever, phlebitis, neuritis, dermatitis, diabetes, albuminuria, haemophilia, "Bronchomychosis", and oriental sore were diagnosed. ${ }^{42}$ In 1931, diagnoses included bacilliary (sic) colitis, "Uncoumbranous Colitis", hookworm, jaundice, tropical ulcer, tropical eczema, anaemia, septic pneumonia, tropical erythema, and encephalitis lethargica. ${ }^{43}$ In the final year of its existence, the following diagnoses were made: "Metadysentery", "Para Malta Fever", psoriasis, sandfly fever, debility, endocarditis, Parkinson's disease, "Blockage of Lymphatic Glands of Leg", "Para-maletensis", and oedematous hands. ${ }^{44}$ Many of these entities, it will be noted, do not represent "tropical" diseases at all. Financial remuneration from patient care was relatively insignificant, "but it must be remembered that in the interests of science individual free patients are kept in the hospital for many months under observation and treatment, and

${ }^{39}$ RIHTD, Annual Report, 1927, pp. 17-18.

${ }^{40}$ RIHTD, Annual Report, 1928 , pp. 27-8.

${ }^{41}$ RIHTD, Annual Report, 1929, pp. 18-19.
${ }^{42}$ RIHTD, Annual Report, 1930, pp. 30-1.

${ }^{43}$ RIHTD, Annual Report, 1931, p. 24.

${ }^{44}$ RIHTD, Annual Report, 1932, p. 48. 


\section{G C Cook}

only a limited number of beds can be used for paying patients" (emphases added). ${ }^{45}$ It is quite clear that the hospital was simply not paying its way.

\section{Other RIHTD Activities}

Two significant events were recorded in the 1928 Report, namely the formation of an "Industrial Anti-Malarial Advisory Committee" which aimed to give direct assistance in disease prevention to tropical industries, and the initiation of local committees in tropical countries (notably India and Ceylon) to be started by Watson and Stevens. ${ }^{46}$ The following Report referred to a malarial expedition to the copper mines of Northern Rhodesia (now Zambia); ${ }^{47}$ Simpson, Dr A C Dalzell and Mr C R Harrison (who had carried out "successful anti-malarial work in the Malay States" between 1906 and 1928) were involved. Other reports outlined ongoing expeditions to India (1928-9); Central Africa (1929); Northern Rhodesia (1930); South Africa, the Belgian Congo, and East Africa (1931); and Malaya (1930). Watson also visited Southern Rhodesia (now Zimbabwe) in 1932, and Natal, Zululand, Bechuanaland and the Port of Beira in $1930{ }^{48}$ In 1932 Watson described in The Times how in 1929, when the mines had first requested help from the RIHTD, "malaria, blackwater fever, [typhoid,] dysentery and pneumonia were [still] a serious economic handicap" ${ }^{49}$ Since that date, health had improved immeasurably (he cited data from Malaya as well as Northern Rhodesia) and malaria was no longer a significant health risk. This latter fact was emphasized in a Times leading article in the same issue: "the control of malaria is the essential foundation of all tropical medicine. Until that has been achieved other measures are likely to yield but meagre results". ${ }^{50}$ These pieces both followed two articles written by a "Special Correspondent", which had been published in the same newspaper in $1931 .{ }^{51}$ In an excellent description of working and living conditions in Northern Rhodesia, the writer considered: "it is hard to believe that this will ever be a white man's country unless the white man can grow a black skin to keep out the sun". But, the greatest hazard (Watson concluded) came from "tropical diseases"-especially malaria. ${ }^{52}$ An excellent booklet (originally published in 1917) on Prevention of malaria by Dr Cuthbert

\footnotetext{
${ }^{45}$ RIHTD, Annual Report, 1926, p. 13.

${ }^{46}$ RIHTD, Annual Report, 1928, pp. 10-11.

${ }^{47}$ RIHTD, Annual Report, 1929, p. 15.

${ }^{48}$ RIHTD, Annual Reports: 1930, pp.

15-27; 1931, p. 17; and 1932, pp. 24-33.

${ }^{49} \mathrm{M}$ Watson, 'The enemy in Rhodesia: combating the mosquito: a successful year', The Times, 1 July 1932, pp. 15-16; see also M Gelfand, Northern Rhodesia in the days of the charter: a medical and social study 1878-1924, Oxford, Basil Blackwell, 1961.
}

\footnotetext{
50 'The fight against malaria', The Times, 1 July 1932, p. 15.

51 'Empire copper: the new mines of Rhodesia: 1. A task for the geologist', The Times, 9 Feb. 1931, p. 13; 'Empire copper: II. Recruits to Rhodesia: a mixed mining community', The Times, 10 Feb. 1931, pp. 15-16.

${ }^{52}$ Watson, op. cit., note 49 above, p. 16.
} 


\section{A Difficult Metamorphosis}

Christy $^{53}$ was enthusiastically mentioned in several reports; ${ }^{54} 25,000$ copies-for free distribution by the RI-had been printed.

The objectives of the Anti-Malarial Advisory Committee were to "keep industry in touch with science, to make the tropics healthy and expand the markets of the world"; the Committee consisted of representatives of rubber, tea, oil, sugar, gold, copper and mining industries, as well as RI members. ${ }^{55}$ The 1930 Report also contained further reference to the India Branch of the RI; Dr G C Ramsay (who possessed a great deal of knowledge gained in Assam) had been appointed Principal. His knowledge of malaria control in Assam and northern Bengal tea estates would be utilized for the general benefit of the tea industry. ${ }^{56}$ In the following year, a most successful twelve months of the India Branch was recorded despite "the acute depression from which the tea industry [had] suffered during the year under review" ${ }^{57}$ The Report for 1932 concluded: "The India Branch will have completed its first three years on July 31, 1933, and it has proved of great value to the Tea Industry in Assam and Bengal". ${ }^{58}$ Apart from accepted control measures, the value of atebrin (mepacrine) and plasmoquine (pamaquine) were at that time undergoing evaluation. There was "great difficulty in ascertaining the truth about new drugs in general. The Medical Press is flooded with communications, many of which are of no assistance in forming an accurate and objective opinion". The Report also concluded that quinine "had the merit of being the one drug which could be placed in the hands of the layman with confidence that it could do no harm". There was recognition that non-immunes (i.e. Europeans and Bengali clerks) required special protection against blackwater fever. The best type of oil for use in mosquito eradication and the value of Paris Green were also undergoing evaluation. ${ }^{59}$

Previously, the 1931 Report had mentioned a study by Watson concerning the disappearance of Plasmodium spp infection from the English Fen district; it was considered that this work might have a relevance to malaria control in tropical countries. ${ }^{60}$

The RIHTD also organized courses in "malaria control" (the physical features of the nearby Wimbledon Common and Richmond Park were utilized and the

\footnotetext{
${ }^{53}$ It had first appeared as 'Notes on malaria for officers and men', Lancet, 1917, ii: 485-6. The Executive Committee of the RIHTD (with Christy's permission) published it for free distribution to residents in the tropics. Cuthbert Christy (1863-1932) graduated MB at Edinburgh and served in South America, West Indies, Africa and India. He took part in a Liverpool School of Tropical Medicine expedition in East Africa and became a lecturer at that school. He later continued his expeditions to Central Africa and died as a result of wounds inflicted by a buffalo whilst Chairman of an "International Commission to inquire into the alleged existence of slavery in Liberia" (The Times, 7 June 1932, p. 16); C Christy,
}

Mosquitos and malaria: a summary of knowledge on the subject up to date; with an account of the natural history of some mosquitos, London, Sampson Low, Marston, 1900; G C Cook, 'Correspondence from Dr George Carmichael Low to Dr Patrick Manson during the first Ugandan sleeping sickness expedition', J. med. Biog., 1993, 1: 215-29.

${ }^{54}$ See RIHTD, Annual Reports, 1929, pp.

16-17; 1930, p. 30; and 1932, p. 46.

${ }^{55}$ RIHTD, Annual Report, 1930, p. 28.

${ }^{56}$ Ibid., pp. 20-2.

${ }^{57}$ RIHTD, Annual Report, 1931, pp. 21-4.

${ }^{58}$ RIHTD, Annual Report, 1932, pp. 30-33.

${ }^{59}$ Ibid., pp. 36-41.

${ }^{60}$ RIHTD, Annual Report, 1931, p. 20. 


\section{GC Cook}

likelihood of their being populated by malaria-carrying mosquitos considered); the fifth Malaria Control Course, for example, was held in July 1932 and "was attended by 35 doctors, planters, and engineers". ${ }^{61}$ The 1932 Report also highlighted the potential hazards of yellow fever (a topical subject) - which with fast modern transport had the potential to spread from west to east Africa and subsequently to Asia, including India: "Yellow fever was carried [the writer reminded his readers] from the West Coast of Africa to America in sailing ships". Not just the disease, but also the mosquito was transferred, "as it has been shown that the mosquito responsible for the carrying of yellow fever, which is now common throughout America, was not indigenous to that country, but was imported. The disease reached America with its non-immune population and the civilisation of Central America practically disappeared. While it is a mild disease among the immune population of the West Coast of Africa, it is deadly to non-immunes." 62

\section{Illness and Death of Ross}

The 1927 Report recorded that Ross (then aged seventy) had suffered a "paralytic" stroke in August of that year; ${ }^{63}$ after convalescing he returned to the Institute in January 1928. Five years later, the 1932 Report contained this melancholy notice: "On the death of Sir Ronald Ross [at the RIHTD on 16 September $1932^{64}$ ], Sir Aldo Castellani, K.C.M.G., D.S.C., M.D., F.R.C.P., became Senior Director of the Ross Institute and automatically Director-in-Chief of the Institute". ${ }^{65}$

Reference had been made in 1928 to the Ross Archive, which had been bought by Lady Houston and "presented to the British Museum";66 the Trustees of the Museum felt, however, that the manuscripts and letters dating from 1899 onwards would be more useful to students of tropical medicine if placed in the RI; they were therefore deposited there. Eli Chernin has outlined Ross's enormous contributions to malaria research and has highlighted a lack of monetary reward, which left him a far from wealthy man. ${ }^{67}$

${ }^{61}$ RIHTD, Annual Report, 1932, p. 44.

${ }^{62}$ Ibid., pp. $39-40$.

${ }^{63}$ RIHTD, Annual Report, 1927, p. 20.

${ }^{64}$ See Cook, op. cit., note 8 above; Nye and Gibson, op. cit., note 8 above, p. 266. After a long illness (which began with a cerebrovascular accident-presumably thrombotic-in August 1927) Ross lapsed into coma in September 1932, and died in the presence of the Matron of the RIHTD-Miss M Gray. His funeral service was held at Holy Trinity Church, West Hill, London SW15, and he was buried on 20 September beside Lady Ross (who had died in September 1931), at the Putney Vale Cemetery (The Times, 21 Sept. 1932 , p. 13); the grave is now extremely poorly maintained (G C Cook, 'The grave of Sir Ronald Ross FRS (1857-1932), Lancet, 1999, 354: 1128). A memorial service was held at the same church on 25 September (The Times, 26 Sept. 1932, p. 15). Ross had for many years been a heavy cigarette smoker, and, apart from vascular disease, suffered from insulin-dependent diabetes mellitus and intermittent claudication.

${ }^{65}$ RIHTD, Annual Report, 1932, p. 23.

${ }^{66}$ RIHTD, Annual Report, 1928, p. 28; see also Nye and Gibson, op. cit., note 8 above, p. 280.

${ }^{67}$ E Chernin, 'Sir Ronald Ross, malaria, and the rewards of research', Med. Hist., 1988, 32: 119-41. 


\section{A Difficult Metamorphosis}

The work of the RIHTD was doubtless of great value in a preventive capacity (most was, however, carried out not at Putney, but in the field-in Asia and Africa), but the clinical work (both patient care and research) was exceedingly unimpressive and undistinguished (see above and Figure 3); the "clinical" research topics and subsequent publications were disappointing. The emphases doubtless reflected Ross's own interests and capabilities.

\section{Towards Amalgamation with the LSHTM}

Following the move to Endsleigh Gardens, WC1, in 1920, the Seamen's Hospital Society (SHS) had continued to sponsor the established clinical tropical medicine institution-now renamed the Hospital for Tropical Diseases (HTD) ${ }^{68}$ Numbers of patients had increased significantly since the early days at Albert Dock. ${ }^{69}$ The London School of Hygiene and Tropical Medicine (LSHTM) had been officially opened in 1929 as a public health institution, following a generous gift of $\$ 2$ million from the Rockefeller Foundation: ${ }^{70}$ apart from incorporating a Department of Clinical Tropical Medicine, this school had largely severed its links with the HTD.

As the following correspondence (preserved in the SHS archive) makes abundantly clear, there were several key players (some more demanding than others) involved in the negotiations (Table 1)-which ultimately proved successful-on a future role for the RIHTD.

On 12 April 1933, R W Harris (Secretary, LSHTM) wrote to R E V Bax (Secretary, SHS) informing him that discussions between the LSHTM and the RIHTD, on the future role of the latter institution, had the previous evening reached a "more formal stage", ${ }^{71}$ Sir Austen Chamberlain (Chairman, Court of Governors, LSHTM, and also Vice-Chairman, SHS) ${ }^{72}$ Sir (Edwin) Cooper Perry (Chairman, LSHTM) and W W Jameson (Dean, LSHTM) ${ }^{73}$ had met McLeod (Chairman), Mr Walter Shakspeare (Vice-Chairman) and Lord Queenborough (Treasurer). The latter three were representing the RIHTD. It is unclear how long negotiations for the amalgamation had been proceeding. As a result of this

\footnotetext{
${ }^{68}$ Cook, op. cit., note 3 above, pp. 218-41; G C Cook, 'The Seamen's Hospital Society: a progenitor of the tropical institutions', Postgrad. med. J., 1999, 75: 715-17.

${ }^{69}$ Cook, op. cit., note 10 above, pp. 675-6; see also G C Cook, A J Webb, 'The Albert Dock Hospital, London: the original site (in 1899) of tropical medicine as a new discipline', Acta Tropica, 2001, 79: 249-55.

${ }^{70}$ Cook, op. cit., note 3 above, pp. 242-59.

${ }^{71}$ R W Harris to R E V Bax, 12 April 1933, SHS Archive.

${ }^{72}$ Sir (Joseph) Austen Chamberlain, KG (1863-1937), elder son of Joseph Chamberlain had served as Chancellor of the Exchequer (1903-6 and 1919-21), Secretary of State for
}

India (1915-17), Secretary of State for Foreign Affairs (1924-29) and First Lord of the Admiralty (1931).

${ }^{73} \mathrm{~W}$ W (later Sir Wilson) Jameson, GBE, FRCP (1885-1962) had been Lecturer in Public Health and Preventive Medicine at Guy's Hospital, before becoming Dean and Professor of Public Health at the London School of Hygiene and Tropical Medicine. He was also Medical Adviser to the Secretary for the Colonies. Between 1940 and 1950 he was Chief Medical Officer of the Ministries of Health and Education; see N M Goodman, Wilson Jameson: architect of national health, London, George Allen and Unwin, 1970. 


\section{GC Cook}

meeting, a "revised draft agreement" for an ultimate solution to the dilemma regarding the future of the RIHTD. was issued ${ }^{74}$ the intention was to submit this document to the executive and then to members of the RIHTD. The future of the Hospital had to be treated separately, it was stated. The objectives were:

(i) The creation of a Department of Tropical Hygiene (The Ross Institute of Tropical Hygiene) within the LSHTM;

(ii) The addition of 2 or more members nominated by the RIHTD to serve on the Court of Governors of the LSHTM (one of them to be appointed to the Board of Management);

(iii) To set up a Standing Committee (with powers of co-option) to administer the RI (this to consist of 2 or more members of the Board of Management of LSHTM together with the Dean, LSHTM, one of whom should be Chairman);

(iv) To provide Castellani with laboratory accommodation and "assistance adequate for the carrying-out of his researches ... on a scale not less than that on which he has hitherto carried out his researches at the [RIHTD]";

(v) To appoint Watson as Director of the Department of Tropical Hygiene (RI) on terms "not less favourable than those enjoyed by him under his appointment with the [RIHTD]";

(vi) To provide Watson "with office and laboratory accommodation and staff ... on a scale not less than that on which he has carried out his duties at the [RIHTD]";

(vii) To authorize the Standing Committee "to sanction ... programmes of preventive and other measures, in tropical or subtropical countries, for the control of malaria and other tropical diseases";

(viii) To authorize the Standing Committee to organize the collection of funds for the LSHTM;

(ix) To appoint the Secretary of the RI to a position on the staff of the LSHTM on terms comparable with those of his current appointment;

(x) To take into consideration estimates "prepared by the Finance and General Purposes Committee of the [LSHTM] ... of the expected yield of sums collected by the RI".

Chamberlain wrote to Lord Lloyd of Dolobran, Chairman of the SHS (Figure 4), ${ }^{75}$ the same day: "The Institute [i.e. the RIHTD], especially during the lifetime of Ronald Ross, has enjoyed a remarkable publicity and a measure of support

\footnotetext{
74 'Draft of an agreement between the London School of Hygiene and Tropical Medicine and the Ross Institute and Hospital for Tropical Diseases (Incorporated)', SHS Archive.

${ }^{75}$ George Ambrose Lloyd, 1st Baron Lloyd of Dolobran, PC, GCSI, GCIE, DSO (1879-1941) had travelled extensively. He had had a distinguished career as an Empire administrator, and had also been honorary attaché to the British
}

embassy at Constantinople, Governor of Bombay (1918-23), High Commissioner for Egypt and the Sudan (1925-9) and Chairman of the British Council (1936). He was Chairman of the Seamen's Hospital Society from 1932 until 1937. He became Secretary of State for the Colonies in 1940; see 'The Rt Hon Lord Lloyd of Dolobran, PC GCSI, GCIE, DSO', Seamen's Hospital Society Quarterly Magazine, 1932, 4 (2): 9. 


\section{A Difficult Metamorphosis}

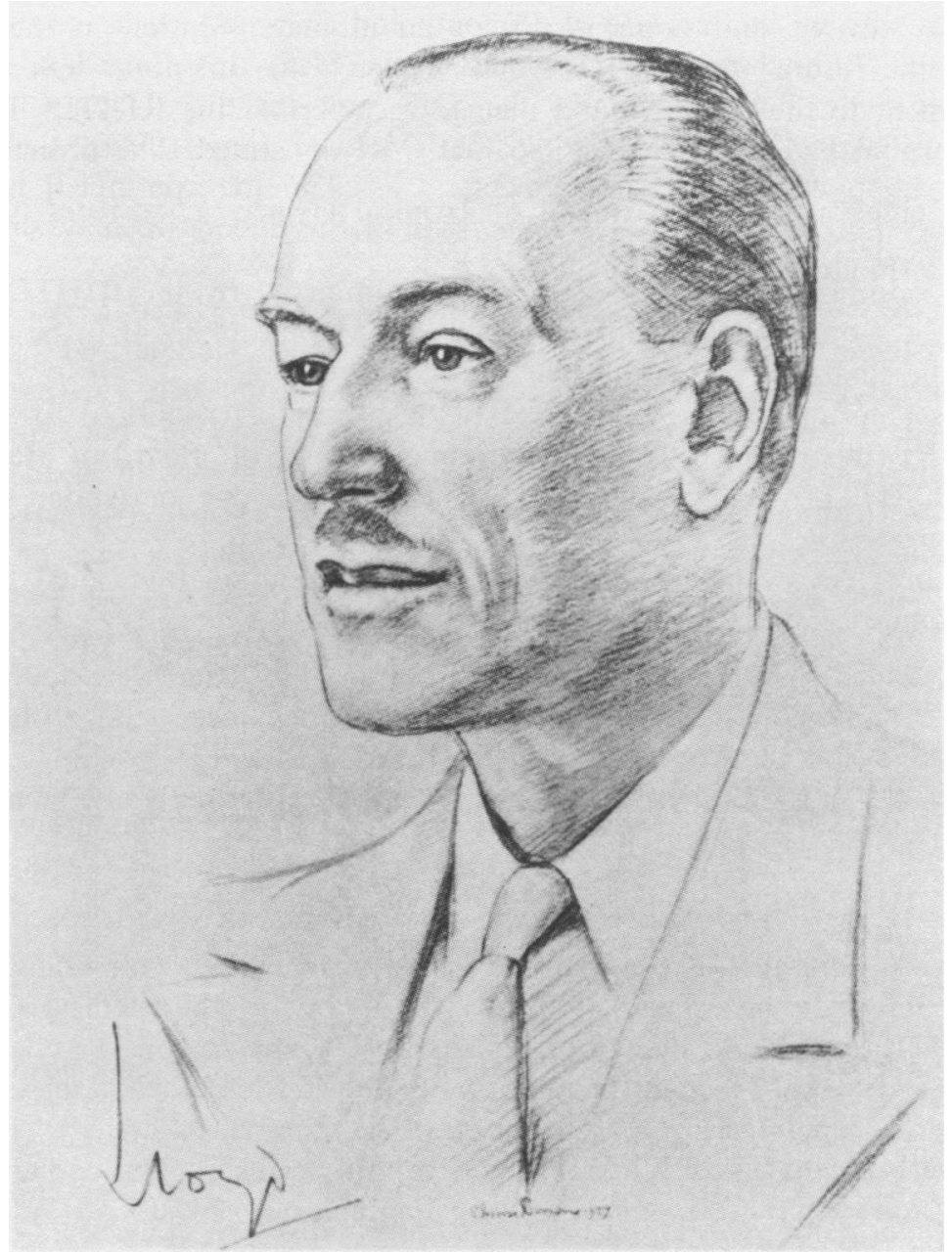

Figure 4: Lord Lloyd of Dolobran, Chairman of the Committee of Management of the SHS, 1932-7, and President, 1938 (source: Seamen's Hospital Society Quarterly Magazine, 1938, 10 (2): 4).

which, at any rate on the clinical and scientific side, is disproportionate to its real activities". Despite this, he continued, "it performs in the field of Tropical Hygiene a very important work which does not overlap with what is at present done [at the LSHTM] ... Our real difficulty is that by its constitution [the LSHTM] can do nothing in the way of offering accommodation for the hospital side of the Ross Institute ... Sir Aldo Castellani is Director-in-Chief of the [RIHTD] and is responsible for the control of the hospital". Chamberlain ended his letter: "Our inability to provide any beds to replace those at Putney seems to be the one remaining obstacle in the path of the amalgamation of the two 


\section{GC Cook}

Institutions with all the increase of economy and efficiency which it would enable us to make". ${ }^{76}$ Lloyd replied, on behalf of the SHS, that Castellani should be given some beds, but not put on the SHS staff (at the HTD); Chamberlain subsequently wrote to Lloyd saying that McLeod (representing the RIHTD) would be happy with this arrangement; "Castellani [he continued] is showing himself very unreasonable and if he persists in this mood we may simply have to go on without him". ${ }^{77}$

Dr P H Manson-Bahr ${ }^{78}$ (representing the HTD) then visited Lloyd to discuss matters further; he followed this with a letter which summarized his position (and presumably that of the HTD staff also), indicating that he was willing to offer Castellani a position on the Associated Staff of the HTD but other "special titles" could not be offered, which meant "that he can put in as many of his cases as the Hospital can accommodate". Manson-Bahr also considered that the HTD should be better represented on the Board of Management of the SHS, and that "three or four private rooms on one of the floors of the [HTD] be renovated and the fittings improved so as to attract a better class of patient" (emphasis added). ${ }^{79}$ The sentiments expressed in this letter were forwarded by Lloyd to Chamberlain, "I hope ... that this offer meets the wishes of the [LSHTM] and also the Council of the [RIHTD]". ${ }^{80}$ In a reply to Lloyd, MansonBahr thanked him for a further letter (and for a copy of his reply to Chamberlain) ${ }^{81}$

\section{Castellani's Response to the Deliberations}

At his own request, Castellani visited Lloyd in late May; in a follow-up letter the day afterwards, he asked that Lloyd "point out to the Medical Committee [of the HTD] that should they not see their way to appoint one or two members of the Ross Tropical Hospital on the [presumably full-time] staff, these members might approach, with great probability of success [emphasis added], some other hospital with the object of starting some tropical wards". ${ }^{82}$ The contents of this interview and letter were immediately communicated by Lloyd to MansonBahr, ${ }^{83}$ who replied to Lloyd:

It should be our policy to close the [RIHTD] up as a worthless institution, and at the same time to avoid burdening ourselves with Sir A. Castellani-because, you can take it from me, he wo'nt do us any good at all. He must either take the offer of membership

\footnotetext{
${ }^{76}$ A Chamberlain to Lloyd of Dolobran, 12 April 1933, SHS Archive.

${ }^{77}$ A Chamberlain to Lloyd of Dolobran, 13 May 1933, SHS Archive.

${ }^{78}$ Dr P H (later Sir Philip) Manson-Bahr, CMG, DSO, FRCP (1881-1966) was Consultant Physician at the HTD and Director of the Clinical Division of the London School of Hygiene and Tropical Medicine. He had served as President of the Royal Society of Tropical Medicine and Hygiene (1947-9).
}

\footnotetext{
${ }^{79} \mathrm{P}$ H Manson-Bahr to Lloyd of Dolobran, 17 May 1933, SHS Archive.

${ }^{80}$ Lloyd of Dolobran to A Chamberlain, 19 May 1933, SHS Archive.

${ }^{81}$ P H Manson-Bahr to Lloyd of Dolobran, 20 May 1933, SHS Archive.

${ }^{82}$ A Castellani to Lloyd of Dolobran, 31 May 1933, SHS Archive.

${ }^{83}$ Lloyd of Dolobran to P H Manson-Bahr, 31 May 1933, SHS Archive.
} 


\section{A Difficult Metamorphosis}

of the Associated Staff, or refuse it ... Perhaps the [SHS] does not realize what his so called research work would cost the Hospital. I know well that he keeps his poor experimental victims in Hospital for months on end and it would cost the Hospital at least $£ 5$ per patient per week and I make so bold as to say that the value of such research work would be nil. ${ }^{84}$

Manson-Bahr continued by assuring Lloyd that "the permanent value of research work already done at the [HTD] is a thousand times more valuable than anything Sir A.C. himself has done".

A day later, Castellani wrote a further letter to Lloyd: "Should the Medical Committee of the Endsleigh Gardens Tropical Hospital refuse to have members of the Ross Hospital on the staff, would it be possible for the [SHS] to take over the Ross Tropical Hospital retaining on it the present staff, or at least myself." 85 These additional sentiments were duly transmitted to Manson-Bahr, whose comments leave no doubt as to his feelings on the matter:

I have your letter of $2^{\text {nd }}$ of June enclosing a communication from Sir Aldo Castellani. My answer is straight \& to the point. This is the sort of intrigue I am up against \& I mean to fight these machiavellian methods to the last ditch. This is a threat \& a bluff \& in view of this I consider that the offer of membership of the Associated Staff should be withdrawn.

Sir Aldo Castellani cannot do the Tropical Hospital [HTD] any more harm than he has already done. I happen to know that his views are not those of the Council of the Ross Institute \& you can take it from me that there is not a decent Hospital in London which will give him any facilities at all $\ldots{ }^{86}$

Lloyd wrote to Castellani telling him that it would be quite impossible for the [SHS] to take over the Ross Tropical Hospital, ${ }^{87}$ and to Chamberlain indicating that the Hospital Board had agreed to "Castellani being given a post on the Associated Staff"; he doubted however that Castellani would accept. ${ }^{88}$ Meanwhile, McLeod also had written to Chamberlain informing him that, at a formally convened meeting of the Executive Committee of the RIHTD held two days previously, it had been decided definitely to proceed with the amalgamation of the Ross Institute and the LSHTM; a fourth draft was produced which contained five clauses, two of which stated: "iii) That Sir Aldo Castellani shall be provided with a definite position on the staff of the School [LSHTM] carrying a title of 'Director', and (iv) That three beds and a position on the associated staff are to be secured for the use of Sir Aldo Castellani in the [HTD]." 89

\footnotetext{
${ }^{84} \mathrm{P}$ H Manson-Bahr to Lloyd of Dolobran, 1 June 1933, SHS Archive.

${ }^{85}$ A Castellani to Lloyd of Dolobran, 2 June 1933, SHS Archive.

${ }^{86} \mathrm{P}$ H Manson-Bahr to Lloyd of Dolobran, 3 June 1933, SHS Archive.
}

\footnotetext{
${ }^{87}$ Lloyd of Dolobran to A Castellani, 15 June 1933, SHS Archive.

${ }^{88}$ Lloyd of Dolobran to A Chamberlain, 15 June 1933, SHS Archive.

${ }^{89} \mathrm{C}$ C McLeod to A Chamberlain, 15 June 1933.
} 


\section{GC Cook}

In mid-June also, Harris wrote to Sir James Michelli (Treasurer, SHS); ${ }^{90}$ the enclosed letter was intended (assuming the latter approved of it) for the eyes of Lloyd as well. "[I]t would, I think, help enormously if [the HTD] were ... to say that they would be prepared to perpetuate the memory of Ronald Ross by naming a ward in the Hospital "The Ross Ward"' and in return the HTD would "as a gesture of goodwill" be offered by the RIHTD a "substantial donation which might well be something of the order of $£ 1,000 \ldots$ This would effectively silence any critics of the proposed agreement who were urging that the Hospital side of the Ross Institute was not being sufficiently recognised". "I can tell you [Harris continued] that the Chairman and other leading members of the Executive Committee of the [RIHTD] are far more concerned with honouring the name of Ross than they are with the personal prestige of any member, however distinguished, of the Staff of the Ross Institute"..$^{91}$ An anonymous memorandum dated 20 June stated that: "Lloyd [had] himself personally agreed to the Hospital accepting the $£ 1,000$ if offered and also to the Hospital naming a ward the 'Ross Ward",;2 he did not, however, approve of Castellani being given three beds.

But the Castellani dilemma refused to go away. A few days later, Harris wrote to Bax enclosing a letter which Chamberlain had received from McLeod, ${ }^{93}$ the latter (writing on behalf of the RIHTD) had made a further plea that three beds and a position on the Associated Staff should be secured at the HTD for the use of Castellani. Following a discussion with Lloyd, Bax duly replied to Harris that it was "not possible under the constitution of the Associated Staff to allot to any of its members beds in the open wards. Lord Lloyd asks me to say that it is a matter of regret to him that the Society is unable to meet this particular request of the [RIHTD] and the LSHTM". 94

At the end of June, Jameson involved himself personally in the negotiations; his intervention, he explained to Bax, had resulted from an unofficial talk (at the LSHTM) the previous evening at which Dr G C Low (1872-1952) (Physician, HTD and Albert Dock Hospital), Castellani, Stevens and he were present. He considered that two paragraphs of an enclosed document were "not altogether unreasonable and might perhaps receive favourable consideration from the [SHS]". ${ }^{55}$ These paragraphs stated that "Castellani [would] have the right to recommend for admission and to have under his own personal charge non-paying patients in any ward of three beds which [might] be named the Ross Ward in the [HTD]", and that the HTD would publish the list of the Associated Staff,

\footnotetext{
${ }^{90}$ Sir James Michelli, CMG (1853-1935) had been Secretary of the Seamen's Hospital Society from 1887 until 1927, and the London School of Tropical Medicine from 1899 (the date of its foundation) until 1924.

${ }^{91}$ R W Harris to J Michelli, 17 June 1933, SHS Archive.
}

\footnotetext{
${ }^{92}$ Memorandum, 20 June 1933, SHS Archive.

${ }^{93}$ R W Harris to R E V Bax, 23 June 1933, SHS Archive.

${ }^{94}$ R E V Bax to R W Harris, 30 June 1933, SHS Archive.

${ }^{95}$ W W Jameson to R E V Bax, 30 June 1933, SHS Archive.
} 


\section{A Difficult Metamorphosis}

indicating after Castellani's name that he was in charge of the Ross Ward of which he was to be designated Physician in charge. ${ }^{96}$

Various consultants who were on the Staff of the HTD, then had their say in the controversy. Neil Hamilton Fairley, Director of the Pathological Department, wrote to Low indicating that he agreed to Castellani being given the right to send in and to have under his personal charge non-paying patients in the Ross Ward, providing that he did not exceed three beds. ${ }^{97}$ Fairley also had no "violent objection" to Castellani being listed as Physician on the Associated Staff, and/or "In charge of the Ross Ward" being added; this was preferable, in his opinion, to "Physician in charge of the Ross Ward". Sir Leonard Rogers (Extra Physician), in a letter to Bax, agreed to the appointment of Castellani to the Associated Staff of the HTD. ${ }^{98}$

\section{Response of the HTD Medical Council, 4 July 1933}

The following motion was carried at the July Medical Council meeting of the HTD and sent forward to the SHS Board "as a recommendation":

That Sir Aldo Castellani, in addition to being offered a position on the Associated Staff, should have the right to send in and have under his own personal charge non paying patients in the "Ross Ward", it being understood that the Ross Ward would contain three beds. ${ }^{99}$

A week later, Stevens, on behalf of the RIHTD, was able to confirm acceptance of this offer in writing to Bax. The day before, McLeod, S H Hargrove (solicitor to the RIHTD) and Stevens had conferred with J A Reid, Counsel for the RIHTD. Reid considered that certain difficulties would be obviated if the "[SHS] were made party to the proposed Agreement and a sum of say $£ 1000$ was paid direct to the Society by the [RIHTD] in sole consideration of the Society naming one of their wards 'The Ross Ward'." Stevens requested approval of this course of action before Reid amended the draft agreement. ${ }^{100}$ Bax duly replied on behalf of the SHS indicating that his Board had "unanimously resolved [the day before] to name a ward in the Hospital 'The Ross Ward' in memory of [Ross]", and furthermore, "they received with pleasure the news that the Ross Institute proposed to make a donation of $£ 1,000$ to the [HTD]." 101 The matter was seemingly concluded by a letter from Bax to Harris approving a "Ross Ward" at the HTD and Castellani being offered a position on the Associated Staff.

\footnotetext{
${ }^{96}$ The document is undated and unsigned, but may have been written by D A C Price. It is in the SHS Archive.

${ }^{97}$ N Hamilton Fairley to G C Low, 1 July 1933, SHS Archive. Neil Hamilton Fairley (1891-1966) was knighted in 1950.

${ }^{98}$ L Rogers to R E V Bax, 3 July 1933, SHS Archive. Sir Leonard Rogers, FRS (1868-1962).
}

\footnotetext{
${ }^{99}$ Extract from the Minutes of the Hospital for Tropical Diseases Medical Council, 4 July 1933, SHS Archive.

${ }^{100}$ H L Stevens to R E V Bax, 11 July 1933, SHS Archive.

${ }^{101}$ R E V Bax to H L Stevens, 13 July 1933, SHS Archive.
} 


\section{GC Cook}

However, the Board, after careful consideration, "regretfully felt themselves unable to agree" to the "suggestion that [Castellani] should have the right to send in and have under his own personal charge, non paying patients in the 'Ross' Ward". ${ }^{102}$

A few days later, a twelve-page printed Memorandum on the proposed amalgamation of The Ross Institute and Hospital for Tropical Diseases with The London School of Hygiene and Tropical Medicine-written by McLeod, was published. ${ }^{103}$ Harris sent a copy to Bax with an accompanying letter. ${ }^{104}$ This paper, which was the subject of an annotation in the British Medical Journal, ${ }^{105}$ succinctly outlined the various organizations which had been involved in the merger. The first suggestion for an amalgamation had come from the Goldsmiths' Company, which had sought to establish, before making a donation to the future institute, that there would be "no overlapping of the activities of the School and the Institute". ${ }^{106}$ The author of the British Medical Journal article quoted McLeod as saying that amalgamation would add to the "value [of the LSHTM] not only to Britain and the British Empire, but to every part of the temperate and tropical zones, the long association of the London School of Tropical Medicine and the [SHS] was preserved by a special agreement, which provided that research and clinical instruction should be carried on in their hospital [HTD] in Endsleigh Gardens, a few minutes' walk from the School." 107 McLeod also pointed out that the memory of Ross would be carefully preserved in the amalgamation.

Harris's letter brought forth a hasty reply from Bax who, after drawing the Memorandum to the attention of the SHS committee, wrote that "the [SHS] was in no way a party to the negotiations which led to the draft Agreement" although it had agreed to elect Castellani to the Associated Staff of the HTD, and further, to name a ward in memory of Ross. ${ }^{108} \mathrm{He}$ continued, "if [the SHS] is to be made a party to the amalgamation, it ought in fairness to be consulted in the disposition and apportionment of the funds of the [RIHTD]". He clearly felt that some, at least, of the RIHTD funds should be channelled to the SHS and not to the LSHTM. A minute of the next SHS Board of Management meeting stated that "this opinion [of Counsel] need not be accepted as authoritative in any way as regards the [SHS]". ${ }^{109}$ The meeting agreed that the matter should be "left in the hands of $\mathrm{Mr}$ [ J C] Nairne [Member of the Committee of Management and Chairman of the Finance Sub-Committee] and the Secretary [Bax]". In a

\footnotetext{
${ }^{102}$ R E V Bax to R W Harris, 13 July 1933 , SHS Archive.

${ }^{103} \mathrm{C}$ C McLeod, Memorandum on the proposed amalgamation of The Ross Institute and Hospital for Tropical Diseases with The London School of Hygiene and Tropical Medicine, London, Loxley Brothers, 24 July 1933.

${ }^{104}$ R W Harris to R E V Bax, 2 Aug. 1933, SHS Archive.

105 'The Ross Institute and the London School of Hygiene and Tropical Medicine', Br. med. J., 1933, ii: 245-6; Cook, op. cit., note 3 above, pp. 259-66.
}

\footnotetext{
106 'The Ross Institute', op. cit., note 105 above, p. 245.

${ }^{107}$ Ibid.; Cook, op. cit., note 3 above, pp. 259-66.

${ }^{108}$ R E V Bax to R W Harris, 8 Aug. 1933, SHS Archive.

${ }^{109}$ Seamen's Hospital Society, Minutes of Board of Management meeting held on 10 August 1933. Minute Book 18 (12 Nov. 1930-12 Dec. 1935), pp. 278-83.
} 


\section{A Difficult Metamorphosis}

subsequent letter to Bax, Harris showed himself to be entirely sympathetic to the SHS line, stating that the SHS need not be brought into the agreement. ${ }^{110}$ In early September, Stevens wrote to Bax confirming conclusions arrived at during a meeting between the two of them: "the simplest [solution which had the backing of the Chairman and Honorary Solicitors of the RIHTD] to meet the wishes of our Counsel ... would be to have a separate agreement between your Society and the Ross Institute which would deal solely with the points which concern the two bodies, and which have already been agreed to."111 The SHS Finance Committee ${ }^{112}$ and subsequently the Board of Management ${ }^{113}$ agreed to meet the wishes of the RIHTD.

This lengthy saga had not yet ended, however. Stevens, who had never had any illusions about Castellani since his first association with the RIHTD, as documented in an unpublished memoir held in the Ross Archive (see this issue, pp. 507-10), again wrote to Bax: "Before calling a meeting of the Executive Committee of the Ross Institute to formally approve the two Agreements, the Chairman wishes to be assured that the Agreements have the approval of the solicitors of all parties... . Counsel has ... considered that if the $£ 1,000$ is transferred as an endowment, we shall be transferring a little more than our total real Endowment Fund-£946.13.0" (emphasis added). ${ }^{114}$ In fact, he wanted to know whether the SHS intended the $£ 1,000$ to be an endowment or be received as a "lump sum". The amalgamation was in effect completed by Bax in a letter to Stevens dated 13 October: "the necessary resolution has been passed by my Board and Quarterly Court, for the sealing of the Agreement between the Ross Institute and ourselves [the SHS] with regard to the 'Ross Ward' and the gift of $£ 1,000$ ". ${ }^{115}$ Stevens duly replied to Bax enclosing three copies of the proposed agreement together with Counsel's opinion. ${ }^{116} \mathrm{~A}$ further letter from Bax to Stevens merely clarified the number of beds (i.e. three), and suggested the following wording: "The [SHS] shall invite Sir Aldo Castellani to join the Associated Staff'.117

The cunning and devious Castellani had not yet received a "knockout blow" however; this is made clear in a letter from Bax to Lloyd written in late October:

\footnotetext{
${ }^{110}$ R W Harris to R E V Bax, 14 Aug. 1933, SHS Archive.

${ }^{111}$ H L Stevens to R E V Bax, 6 Sept. 1933, SHS Archive.

${ }^{112}$ Seamen's Hospital Society, Minutes of Finance sub-committee held on 7 Sept. 1933.

${ }^{113}$ Seamen's Hospital Society, Minutes of Board of Management meeting held on 13 Sept. 1933, Minute Book 18 (12 Nov. 1930-12 Dec. 1935), pp. 284-9.

${ }_{114} \mathrm{H}$ L Stevens to R E V Bax, 4 Oct. 1933, SHS Archive.

${ }^{115}$ R E V Bax to H L Stevens, 13 Oct. 1933, SHS Archive.
}

\begin{abstract}
${ }^{116}$ H L Stevens to R E V Bax, 14 Oct. 1933, SHS Archive; draft agreement, The Ross Institute and Hospital for Tropical Diseases

(Incorporated) - and-The Seamen's Hospital Society, Hargrove \& Co., 8 Iddesleigh House, Caxton Street, Westminster, SW1, 3 Oct. 1933; J A Reid, copy opinion, The Ross Institute and Hospital for Tropical Diseases (Incorporated), Hargrove \& Co., 8 Iddesleigh House, Caxton Street, Westminster, SW1, 4 Oct. 1933.

${ }^{117}$ R E V Bax to H L Stevens, 17 Oct. 1933, SHS Archive.
\end{abstract}




\section{G C Cook}

Friend Castellani has been getting to work as you will see from the enclosed Petition [which had been received by post, by Sir Ion Hamilton Benn, a member of the SHS Finance Committee]. I see that in this morning's "Times" there is a letter from Lady Simpson to the same effect as the Petition.

The Petition is both misleading and inaccurate, but I understand from the Secretary of the [RIHTD] that Sir Charles McLeod ... will deal with it. ${ }^{118}$

Lady Simpson in her letter to The Times emphasized that the seminal idea behind the RIHTD had come from her late husband and his "pupil and friend" Aldo Castellani, "as a lasting memorial to Sir Ronald Ross after his death" (emphasis added). ${ }^{119}$ To sell this off in entirety, which was what was apparently envisaged, was totally unacceptable; she spoke in glowing terms of the excellence of the clinical care undertaken there. Although she was overall sympathetic to the amalgamation of the non-clinical activities with the LSHTM, she felt that the hospital (and clinical facilities) should remain as "a memorial building where Sir Ronald Ross [both] worked and died". Her husband's major concern clearly involved epidemiology and malaria control-closely allied to Ross's major interests; the clinical dimension was clearly inculcated by Castellani. These sentiments seem in retrospect to have been totally ignored.

\section{The Amalgamation Successfully Completed}

In mid-November, Bax wrote to Stevens thanking him for providing "equipment to furnish the 'Ross Ward' [at the HTD]", adding that arrangements for the transfer would shortly be carried out by Mr D A C Price, Resident Secretary, HTD. ${ }^{120}$ The successful outcome of the amalgamation received high praise and congratulations at the Annual Meeting of the Court of Governors of the LSHTM (a copy of the resolution was forwarded to Bax). ${ }^{121}$ The Court also thanked the SHS "for the friendly and helpful spirit in which they [had] facilitated the execution of the agreement by establishing a Ross Ward in the [HTD]".

The final documents of the Agreement between the RIHTD and the SHS were forwarded "under registered cover" by Stevens to Bax in late November. ${ }^{122}$ These had been approved and sealed at an Executive Committee meeting of the RIHTD in late October and confirmed at an "Extraordinary General Meeting of the Members of the Ross Institute" held a month later at Cannon Street Station Hotel. The documents were duly counter-sealed at the next SHS Board meeting

\footnotetext{
${ }^{118}$ R E V Bax to Lloyd of Dolobran, 20 Oct. 1933, SHS Archive.

${ }^{119}$ M Simpson, 'The Ross Institute', The Times, 20 Oct. 1933, p. 8.

${ }^{120}$ R E V Bax to H L Stevens, 14 Nov., 1933, SHS Archive.
}

\footnotetext{
${ }^{121}$ Resolution passed by the Court of Governors (London School of Hygiene and Tropical Medicine) at a meeting held on 17 Nov. 1933, SHS Archive.

${ }^{122} \mathrm{H}$ L Stevens to R E V Bax, 28 Nov. 1933, SHS Archive.
} 


\section{A Difficult Metamorphosis}

(held in mid-December) and one copy was returned to Stevens two days later. ${ }^{123}$ Finally, Bax wrote to Castellani offering him membership of the Associated Staff of the SHS saying: "This will enable you to admit private patients to the Hospital". ${ }^{24}$ Surprisingly, Castellani accepted the following day. ${ }^{125}$

In order to complete the deal before the year's close, Bax wrote to Stevens acknowledging with "warm thanks" his letter enclosing the donation of $£ 1,000$. ${ }^{126}$ Unfortunately the receipt was made out (by Bax) to the LSHTM instead of the RIHTD; a corrected receipt was immediately sent to Stevens. ${ }^{127}$

The sum total of these negotiations, which had taken nine months or more to complete, was that the HTD (sponsored by the SHS) was "now the only institution of its kind in London" (emphasis added). ${ }^{128}$ Reporting on the amalgamation, the SHS Annual Report for 1933 commented: "The [LSHTM] relies for its clinical teaching upon [the HTD], and members of the Hospital Staff are also members of the School Council". ${ }^{129}$ Thus the correspondence was at last at an end and all obstacles strewn in the path of amalgamation had been removed. The major troublemaker had undoubtedly been Aldo Castellani. ${ }^{130}$

\section{Epilogue}

Why had Castellani taken this obstructive stand? There is no simple answer. $\mathrm{He}$ obviously wanted to retain his title of Director; he also seems to have been generally disliked and distrusted by most of his colleagues at the RIHTD and also those at the HTD. ${ }^{131}$ Castellani was exceedingly ambitious and also intensely inward-looking. He undoubtedly cultivated contact (often at a clinical level) with individuals from the upper strata of society-many of them royals from a number of European countries. His autobiography (published in 1960) described "flamboyantly but vividly ... his extraordinary experiences with Royalties and [his] hobnobbing with other most important personages". ${ }^{132}$ In 1928 an honorary KCMG was conferred on him by George V; this was rescinded in 1940 (he was physician to Mussolini) but reinstated shortly before his death. The Times' obituarist wrote succinctly of his literary contributions: "He poured out papers, mostly on dermatology, but he was apt to let his imagination run riot and many will not agree with his description of the newer tropical diseases". ${ }^{133}$ This

\footnotetext{
${ }^{123}$ R E V Bax to H L Stevens, 15 Dec. 1933, SHS Archive.

${ }^{124}$ R E V Bax to A Castellani, 15 Dec. 1933, SHS Archive.

${ }^{125}$ A Castellani to R E V Bax, 16 Dec. 1933, SHS Archive.

${ }^{126}$ R E V Bax to H L Stevens, 28 Dec. 1933, SHS Archive.

${ }^{127}$ H L Stevens to R E V Bax, 29 Dec. 1933; R E V Bax to H L Stevens, 30 Dec. 1933, SHS Archive.

${ }^{128}$ The Seamen's Hospital Society, incorporated by Act of Parliament, $3^{\circ}$ Gul. IV, Cap IX.
}

\footnotetext{
"Dreadnought", Greenwich. Established 1821. For Sick and Injured Sailors, supported by Voluntary Contributions. One hundred \& thirteenth Annual Report from January $1^{\text {st }}$ to December $31^{\text {st }}, 1933$, London, E G Berryman, 1934, pp. 15-16.

${ }^{129}$ Ibid., p. 16.

${ }^{130}$ Castellani, op. cit., note 2 above, pp. 106-8, 246; obituary, 'Professor Marchese Sir Aldo

Castellani: a distinguished physician', The Times, 5 Oct. 1971 , p. 16.

${ }^{131}$ Castellani, ibid.; obituary, ibid.

${ }^{132}$ Castellani, ibid.; obituary, ibid.

${ }^{133}$ Obituary, ibid.
} 


\section{G C Cook}

interpretation probably applied to most other aspects of this man's ebullient make-up.

In an annotation entitled 'A valuable amalgamation', an anonymous writer in the Lancet for August 1933 (pre-empting the final outcome) had concluded: "By the closing down of the hospital beds at Putney and by the ultimate sale of the property, economies will be effected, while the work will go on not only without interruption but with increased vigour derived from a wise fusion."134 Some months after completion of these negotiations, the "incorporation" was formally recognized.

Absorption of the RIHTD into the LSHTM and HTD, at that time administered by the SHS, could and should have been straightforward. Instead, due to the intervention of one man (largely, it seems, for selfish motives), the saga was protracted and numerous man-hours were lost. Ultimately, diplomacy won the day and the future of the RI was secured. ii: 300 .

134 'A valuable amalgamation', Lancet, 1933, 